\title{
Why are Inheritance Taxes Unpopular?
}

\author{
KEITH DOWDING
}

THE RECENT Conservative party foray, Alistair Darling's response and the furore of letters to leading newspapers have demonstrated that inheritance tax or estate duty is something the public really do not like. So far, complete abolition of inheritance tax does not seem to be a serious contender for policy debate in the UK. Yet, as Karen Rowlingson shows, a concerted campaign against the tax could well win support in the UK, as it did in the USA. Rajiv Prabhakar shows a residual suspicion of inheritance tax amongst the British people through his focus group research. For many of us, such outright hostility to inheritance taxes is puzzling. Stuart White amply demonstrates that most of the arguments against inheritance or wealth taxes have little analytic or normative grounding. To be sure, taxes are not generally popular. But people recognise that tax is necessary in order to provide for the public and welfare goods that benefit most of us, even if many people are suspicious that our taxes are not always wisely spent. Indeed, if we go back a few years, the idea of inheritance or estate duties being morally wrong was hardly on the agenda. For example, Seligman, in the first edition of his classic Essays on Taxation in 1895, states that 'inheritance tax to-day scarcely needs defence', ${ }^{1}$ believing that it was obvious that inheritors do not necessarily deserve the full rewards of their benefactors. When other forms of taxation were lower, estate duty was deemed both socially and morally desirable. Of course, since then the burden of taxation overall has increased as the welfare state has developed. But this, in itself, should not affect our attitudes towards inheritance tax. The puzzle is why inheritance tax is so unpopular relative to other taxes. Inheritance taxes should be progressive-unlike sales taxes, which are flat or regressive. Given the structure of society, inheritance taxes ought to benefit rather than harm a greater number of people.

Political economists argue that the modern state has grown in size due to the extension of the franchise. Meltzer and Richard, for example, use a general equilibrium model where the size of the government (that is, taxation raised) is determined by the decisive voter. ${ }^{2}$ Voters with income above the decisive voter favour lower taxation and less redistribution; those below the decisive voter favour higher taxation and more redistribution. Extending the franchise to the poorer classes resulted in a larger state and more redistribution. On this kind of argument, the popularity of different types of taxes ought also to fit with the self-interest of voters, with the more redistributive taxes being more popular than less redistributive ones. However, the logic does not always follow. The least popular tax ought to be any flatrate sales tax (such as VAT), which, broadly speaking, is non-redistributive. Wealth and inheritance taxes should be the most popular tax, since clearly they are the most redistributive. Income tax should be next most popular (especially if it is progressive), with land or housing taxes an outlier, since whilst richer people tend to own more expensive houses and more land, the vagaries of housing markets can make people 'house poor', with 
relatively low incomes given the value of their homes. The puzzle of estate tax repeal in the US as recounted by Karen Rowlingson is precisely why repeal was so popular, given that only 2 per cent of the population actually paid it. Suggesting that people do not vote for simple self-interest but also take moral reasons into account can only take us so far. For as Stuart White shows, the moral arguments against inheritance tax are incredibly poor. The rationally morally aware as well as the rationally self-interested should also be more in favour of inheritance tax than apparently they are. We need to look further at why wealth and inheritance taxes are unpopular. I think the three papers in this symposium take us a long way towards understanding why they might be so, and I will discuss those reasons under the headings of (a) propaganda, (b) fiscal illusion and (c) framing. I will add a further reason based upon (d) the nature of human reasoning that, I suggest, has an evolutionary basis. I will conclude by suggesting that the bias inherent in these four reasons can be overcome to allow people to properly assess the worth of inheritance and wealth taxes and how to sell these ideas.

Karen Rowlingson demonstrates how those in favour of repealing estate taxes ran a superb propaganda campaign. Propaganda does not have to involve misinformation, but the strength of their campaign was based upon neat slogans-'You shouldn't have to visit the undertaker and taxman on the same day'-and narratives that directly appealed to human psyche. However, a major element is the fact that the political elite, led by the President and financed by hosts of millionaires and multimillionaires, led the campaign for abolitionand they only managed partial repeal. This might not tell us much more than the fact that people can be easily misled if enough propaganda is laid out, especially if supported by political leaders. How far that campaign would translate to Britain is unclear. A high-profile television political advertising campaign is not possible in the UK, and without clear political leadership, which seems unlikely in the short term, this means that we should not expect inheritance tax to be repealed in the UK. However, such a possibility cannot be discounted completely, especially if popular newspapers were to take up the call on behalf of their multimillionaire proprietors and their friends. Nevertheless, there is enough head of steam in the campaign for abolition of the tax to ensure that it can bubble away on the political agenda for the time being.

There is an element of fiscal illusion in people's attitudes. Fiscal illusion is normally defined as the public's inability to fully observe the true cost of government, and is usually used to suggest that it enables government to raise more revenue than it otherwise might. However, there is no reason to think that fiscal illusion might not work equally well the other way around. These days, the public tends to think that government is inefficient and yet believes that major government programmes such as health, welfare, education, policing and defence are under-funded. The supposed unpopularity of wealth taxes comes from views expressed when people are queried about the justification of such taxes when considered on their own. However, when such taxes are put into the context of other possible tax systems-and, importantly, in relationship to government expenditure-wealth taxes seem less unpopular. In other words, when the costs and benefits of different types of taxes are compared, especially when they are put together with what the taxes might buy, wealth and inheritance tax do not look so bad. The fiscal illusion engendered by simply considering wealth tax alone can be overcome. That is not to say, of course, that wealth and inheritance tax are popular, but then no tax is popular in its own right. The popularity of all tax systems is relative to one 
another. Similarly, few are going to want higher taxes per se, but when asked whether they are prepared to pay taxes if services are improved, or see services maintained at the same level rather than having tax cuts, the public is prepared for higher tax rates. What people want is their money spent wisely, whether it is spent privately or publicly.

The final category of reasons why people do not like certain forms of taxation has been called 'framing' by Rajiv Prabhakar and Karen Rowlinson. Framing can take many forms and I would like to examine one of these. A technical definition of framing comes from decision theory. Tversky and Kahneman famously show that people break 'invariance', a condition that requires that changes in the description of an outcome should not alter their preferences. ${ }^{3}$ Tversky and Kahneman demonstrate that the outcomes of a gamble might be framed either as asset positions incorporating initial wealth or as gains and losses relative to the status quo. It was from this type of evidence that Kahneman and Tversky developed the idea of the ' $S$ '-shaped utility curve, where people are risk averse when it comes to losses, but are riskseekers when it comes to gains. ${ }^{4}$ Framed in a tax manner, we might ask people whether they would be prepared to accept an increase in personal income of $x$ per cent for sure, or an increase in public goods of $y$ per cent with some probability $p$ (where the value of $y$ is greater than that of $x$ for that person). There must be some probability $p$ at which people would prefer the increase in public goods $y$ to a personal income gain $x$. The framing effect suggests however, that $p$ would have to be higher (or the differential between $x$ and $y$ much higher) for that person to give some money that he or she already has in order to gain those public goods. This can stand as an analogy for the relative popularity of different forms of taxation. Income tax is a relatively popular tax. The reason given in standard public finance texts is that increases in income automatically increase tax revenue even though the tax rate remains the same. Sales taxes are next in relative popularity, again because as sales increase so does tax revenue, even though sales tax remains at the same rate. Traditionally, tax on land or housing is least popular, as the rate needs to increase each year in line with inflation even as the amount relative to the taxpayer's wealth decreases. This can be seen as an element of fiscal illusion, as the extra tax income and sales paid in monetary terms increases without taxpayers realising it. Conversely, it might just be that they have not considered rate rises in line with the inflationary pressures of the public goods that they receive. However, another reason is suggested by the ' $S$ 'shaped utility curve. Income tax is taken at source for most people, so it is never money actually in the possession of the taxpayer. Rates on land and housing are taken from individuals' holdings. Indeed, income tax is less popular with the selfemployed, who do not have it taken at source. Similarly, wealth taxes are taken from a source already considered to be owned by the person paying the tax. The framing effect is to be risk averse, or less willing to pay such tax because it is already perceived to be in the possession of the taxpayer.

The 'S'-shaped utility curve may well have an evolutionary basis, since animals are far more hawkish when defending property (both territory and mates) than when trying to take over the property of their rivals. Such an 'owner' effect might well have evolutionary advantage. The frame for defending inheritance tax must be that it is not a tax on someone who already owns the property. Rather, it is a tax on a recipient and, as Stuart White has argued, we can query the justification of the inheritor's right to that wealth. One reason why inheritance tax may have taken on a new resonance for many people is rising expectations. In the past,

Why are Inheritance Taxes Unpopular? 181 
few people would have expected to have been affected by inheritance tax. The booming housing market has led to inflated expectations. Those expectations are based upon what the valuation that people place on their parent's property and many do not even consider the tax owing on their windfall until it is charged. They see the tax that is being taken from them as part of their property, rather than seeing the post-tax inheritance as their property. This is in complete contrast to attitudes to income tax as most people do not see their pre-tax income since tax is taken at source. Indeed, the strongest feelings about the level of income tax are usually expressed by the self-employed who do see their pre-tax income and then have to pay tax at the end of the fiscal year.

Selling inheritance tax the right way will be important to changing attitudes towards it. The basic moral arguments as laid out by Stuart White need to be at the forefront of such a defence. However, if the tax is sold more explicitly as a recipient tax, then the relative worth of the recipients' holdings would be important. Thus pointing out that people should be taxed according to the total amount they receive in any given year, just as people are taxed on income, would help sell the tax. Perhaps allowing people to write off gifts over several tax years would also help. Giving each person a gift allowance of $£ 200,000$ per year would be generous, but also allowing them to write off a gift in one year over, say, a five-year period would allow people to write off the windfall of the house gain without allowing the rich to completely avoid tax through annual gifts. Furthermore, pointing out that people who gain a house that they live in-say, the adult offspring still living with their parents, or the case of the two sisters sharing a house-can borrow against the capital of the house to pay the tax. Indeed, the tax office itself could 'lend' such money against the house capital until such time as the beneficiary passes on the estate. In these ways, one could avoid one of the most rhetorically telling arguments against inheritance tax and wealth or recipient tax sold to look more as it really is: a reasonable tax that helps redistribute from the rich to the poor without destroying the expectations of those in the middle-those who count electorally.

The above suggestions comprise a version of a capital receipts or accessions tax. This taxes transfers of wealth to a recipient. The notion of a capital receipts tax is not new. In his seminal book Unequal Shares, Atkinson notes that wealth taxes can be crafted in a variety of ways, depending on: whether a tax is placed on stocks of wealth, dividends from wealth or transfers of wealth; whether it is imposed on a donor or recipient; and whether it is applied annually or over a lifetime. ${ }^{5}$ He argues that it is unjust that people acquire wealth that they have played no part in creating. For this reason, he supports a capital receipts tax that taxes the gifts and inheritances that a person receives.

More recently, a capital receipts tax has attracted interest within policy circles. In the United States, Michael Graetz and Ian Shapiro back such as tax in their insistence that the focus of attention within wealth taxation should be on recipients rather than donors. ${ }^{6}$ In Britain, a Fabian Society Commission on Taxation and Citizenship endorsed a capital receipts tax as part of suggested reforms of 'inheritance $\operatorname{tax}^{\prime} .{ }^{7}$ This Commission points out that, strictly speaking, Britain has a system of estates tax rather than inheritance tax, because taxes are levied on a donor's estate rather than on the amount a person inherits. The Commission continues that provisions in existing law (such as the seven-year rule that exempts gifts from taxation provided that the donor lives remains alive for at least seven years) create loopholes that people can exploit to avoid paying an estates duty. The Commission says that 
a shift to a capital receipts tax would be fairer, as this tax would be related to a recipient's ability to pay. Furthermore, this would provide an incentive for a donor to spread their wealth. For example, consider a 25 per cent tax imposed on anything above $£ 20,000$. An estate tax on $£ 100,000$ would yield a $£ 20,000$ tax bill. If this was a capital receipts tax, then the estate could be divided into five $£ 20,000$ bequests, and each of these bequests would not be liable to any tax. Using a Capital Acquisitions Tax in Ireland as an inspiration, the Commission proposes a capital receipts tax that is levied on the gifts and inheritances that a person receives over their lifetime. It suggests that in any year people would be allowed to make gifts of up to $£ 2,000$ and not have to declare this to tax authorities. This is intended to exempt incidental gifts for weddings, birthdays and so on. However, to stop people splitting up their gifts into $£ 2,000$ payments, the Commission says that any set of gifts from one person to another person over one year would count as single gift. The Commission says that a recipient would be allowed over their lifetime to have $£ 80,000$ tax free. Thereafter, a progressive structure could be introduced that would impose a 20 per cent levy on the sum between $£ 80,000$ and $£ 160,000,30$ per cent on the amount from
$£ 160,000$ to $£ 240,000$, and 40 per cent on any amount above $£ 240,000$. My version of a capital receipts tax builds on these suggestions by making provisions that address concerns about having to sell the family home. Of course, the merits of the different versions of a capital receipts tax are open to debate. However, such a tax offers a starting point for engaging with the moral and framing arguments raised in this symposium.

\section{Notes}

1 E. R. A. Seligman, Essays in Taxation, New York, Obscure Press, 2006, p. 133.

2 A. H. Meltzer and S. F. Richard, 'A rational theory of the size of government', Journal of Political Economy, vol. 89, 1981, pp. 914-27.

3 A. Tversky and D. Kahneman, 'The framing of decisions and the psychology of choice', Science, vol. 211, 1981, pp. 453-8.

4 D. Kahneman and A. Tversky, 'Prospect theory: an analysis of decision under risk', Econometrica, vol. 47, 1979, pp. 263-91.

5 A. B. Atkinson, Unequal Shares: Wealth in Britain, London, Allen Lane (Penguin Press), 1972.

6 M. J. Graetz and I. Shapiro, Death by a Thousand Cuts: the Fight over Taxing Inherited Wealth, Princeton, NJ, Princeton University Press, 2005.

7 Commission on Taxation and Citizenship, Paying for Progress: a New Politics of Tax for Public Spending, London, Fabian Society, 2000. 